\title{
TEKNIK PENANGKAPAN IKAN PELAGIS BESAR MEMAKAI ALAT TANGKAP FUNAI (MINI POLE AND LINE) DI KWANDANG, KABUPATEN GORONTALO
}

\author{
Enjah Rahmat \\ Teknisi Litkayasa pada Balai Riset Perikanan Laut, Muara Baru-Jakarta \\ Teregristasi I tanggal: 5 Juni 2006; Diterima setelah perbaikan tanggal: 22 Pebruari 2007; \\ Disetujui terbit tanggal: 25 Mei 2007
}

\section{PENDAHULUAN}

Kabupaten Gorontalo mempunyai luas wilayah $3.456,98 \mathrm{~km}^{2}$ atau $28 \%$ dari luas Propinsi Gorontalo. Secara geografi, kabupaten ini diapit oleh 2 perairan laut yaitu Laut Sulawesi di sebelah utara dan Teluk Tomini di sebelah selatan. Kedua perairan tersebut memiliki potensi yang besar untuk pengembangan perikanan khusus perikanan tangkap. Menurut Laporan Kantor Dinas Perikanan dan Kelautan Kabupaten Gorontalo produksi perikanan laut pada tahun 2004 mencapai 7.769,2 ton atau meningkat $5,4 \%$ dibanding dengan tahun 2003 yang hanya mencapai $7.167,6$ ton. Produksi $81 \%$ tersebut merupakan hasil tangkapan nelayan di Laut Sulawesi sedangkan sisa $19 \%$ adalah berasal dari hasil tangkapan nelayan yang beroperasi di Teluk Tomini.

Wilayah Pelabuhan Perikanan Kwandang merupakan bagian wilayah Kabupaten Gorontalo yang berada di sebelah utara dan menghadap ke perairan
Laut Sulawesi. Usaha penangkapan tuna, cakalang, dan tongkol oleh nelayan di Kwandang dilakukan memakai alat pancing ulur (hand line), funai, pukat cincin (purse seine), dan pancing tonda. Di antara alat-alat tersebut yang khusus untuk tuna dan cakalang adalah alat tangkap funai.

Funai adalah alat tangkap yang terdiri atas bagianbagian joran yang terbuat dari bahan bambu (bamboe's pole), tali pancing, dan mata pancing (Gambar 1). Mata pancing yang digunakan ada 2 macam yaitu yang berkait balik dan tanpa kait. Mata pancing yang paling banyak digunakan adalah mata pancing tanpa kait. Mata pancing ini diselipkan atau disembunyikan pada umpan tiruan (palsu) sehingga tidak secara langsung kelihatan menyolok. Untuk mata pancing yang berkait balik memakai umpan, yaitu umpan hidup atau yang segar. Penggunaan pancing ini hanya dilakukan apabila ikan target sudah tidak suka memakan (menyambar) umpan tiruan. (Subani W. et al., 1989).
A

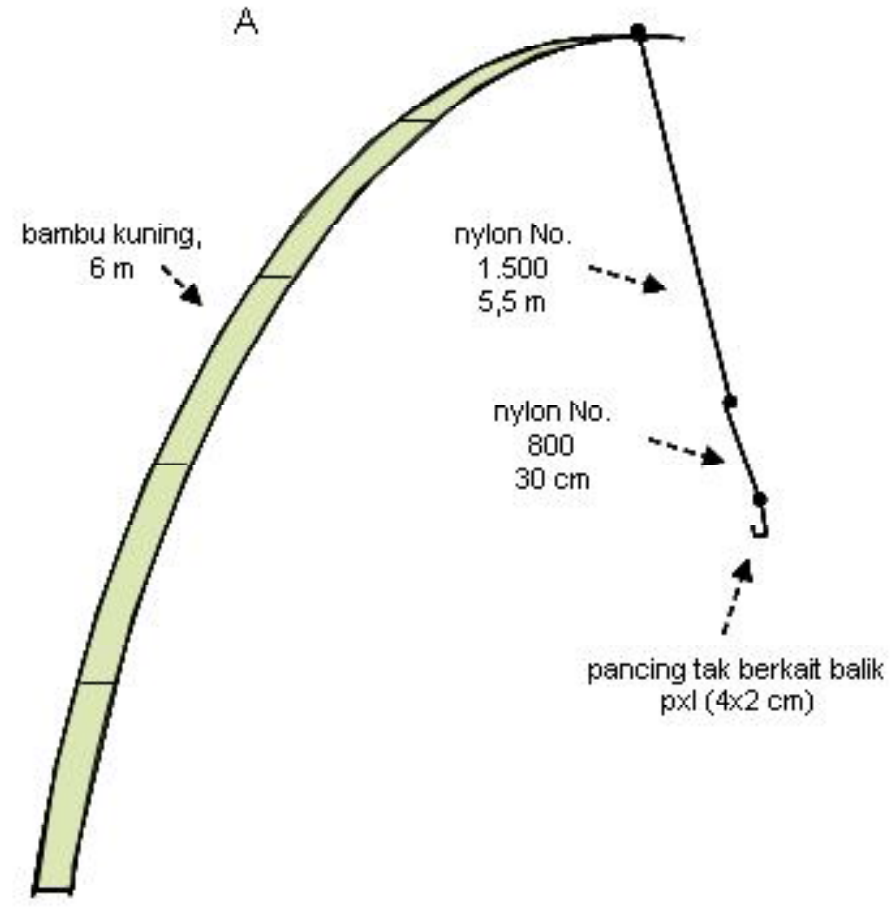

$\mathrm{B}$

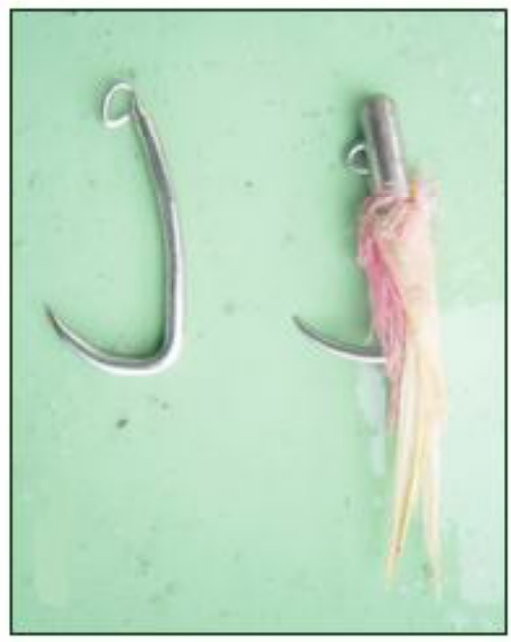

Gambar 1. Desain alat tangkap funai $(\mathrm{A})$ dan mata pancing tanpa kait balik (B). 
Adapun tujuan penulisan makalah ini adalah hendak menguraikan cara penggunaan alat tangkap funai. Untuk mengetahui daerah dan waktu penangkapan, komposisi jenis hasil tangkapan, ukuran panjang, dan bobot jenis ikan pelagis besar hasil tangkapan nelayan Kwandang, maka pada bulan September 2005 telah dilaksanakan penelitian dengan cara mengikuti operasi penangkapan dengan menggunakan alat tangkap funai. Pengumpulan data dilakukan dengan cara pengamatan langsung terhadap pengoperasian alat tangkap funai di atas kapal dan wawancara dengan anak buah kapal.

\section{BAHAN DAN METODE}

\section{Kapal Penangkapan}

Kapal funai yang digunakan dibuat pada tahun 1995, bahan utama kayu dengan ukuran panjang, lebar, dan dalam ( $p x \mid x d=11,10 \times 2,20 \times 0,90 \mathrm{~m}$ ). Mesin penggerak menggunakan motor tempel merk Yamaha 2x40 PK, mesin bantu merk Honda 5,5 PK yang digunakan untuk alat penyemprot air pada saat operasi alat tangkap funai berlangsung dan untuk sirkulasi air pada palka ikan umpan. Sedangkan mesin untuk lampu penerangan menggunakan generator merk Fujisan 1.000 watt. Ada 2 buah palka pada kapal tersebut, yaitu palka bagian tengah untuk menyimpan ikan umpan dengan kapasitas untuk 15 ember ikan umpan yang bercampur air sedangkan palka pada buritan kapal untuk menyimpan ikan hasil tangkapan dengan kapasitas 1 ton. Apabila hasil tangkapan melebihi kapasitas palka, maka ikan hasil tangkapan lain disimpan dalam 4 buah box sterofoam dengan ukuran masing-masing (pxlxd=150x50x40 cm). Sekitar 50 joran siap digunakan untuk alat memancing disimpan di bagian atas kapal. Berdasarkan pada spesifikasi dan cara pengoperasian alat tangkap funai dapat disebut sebagai mini huhate ( mini pole and line) seperti dapat dilihat pada Tabel 1.

Tabel 1. Spesifikasi kapal funai dan huhate yang beroperasi di Laut Sulawesi

\begin{tabular}{lll}
\hline & \multicolumn{1}{c}{ Kapal funai } & \multicolumn{1}{c}{ Kapal huhate } \\
\hline Nama kapal & Kapal contoh 1 & Kapal contoh 2 \\
& (bulan September 2005) & (bulan Juli 2004) \\
Pelabuhan & Kwandang & Bitung \\
Mesin utama & Yamaha, 2x40 PK & Yanmar, 530 PK \\
Mesin bantu & Honda, 5,5 PK & $110 \mathrm{PK}$ \\
Ukuran kapal (pxlxd) & $11,10 \times 2,20 \times 0,90 \mathrm{~m}$ & $20,80 \times 4,80 \times 2,50 \mathrm{~m}$ \\
Jumlah palka & 1 buah (kapasitas 1 ton) & 7 buah \\
Jumlah anak buah kapal & 8 orang & 27 orang \\
& (5 orang pemancing) & (20 orang pemancing) \\
Waktu operasi penangkapan & Pukul 06.00 sampai dengan 19.00 & Pukul 05.00 sampai dengan 18.00 \\
Bahan alat tangkap & Joran, tali nylon, mata pancing & Joran, tali nylon, mata pancing \\
Jenis mata pancing & Mata pancing tanpa kait balik & Mata pancing tanpa kait balik \\
Jenis umpan hidup & Sardin, teri & Malalugis, sardin, dan teri \\
Cara mendapatkan umpan & Menangkap sendiri menggunakan & Membeli dari nelayan soma dampar \\
& seine net & dan bagan \\
\hline
\end{tabular}

Awak kapal berjumlah 8 orang terdiri atas nakhoda, juru mudi, juru umpan, dan pembantu juru umpan, pemancing, juru ikan, dan juru masak. Berikut ini tugas masing-masing anak buah kapal:

1. Nakhoda bertugas mencari gerombolan ikan, menentukan fishing ground dan memegang kemudi pada saat operasi penangkapan ikan umpan hidup.

2. Juru mudi bertugas mengendalikan kemudi.

3. Juru umpan yang dirangkap oleh nakhoda bertugas melempar umpan ke laut untuk merangsang ikan tuna, cakalang, atau tongkol supaya mendekati kapal dan memasuki lahan pemancingan.
4. Pembantu juru umpan bertugas memindahkan umpan hidup dari palka ke bak umpan pada saat operasi penangkapan berlangsung.

5. Pemancing bertugas melakukan pemancingan di buritan kapal.

6. Juru ikan bertugas dalam penanganan ikan hasil tangkapan yaitu pada saat proses penyimpanan dan pembekuan atau pendinginan ikan di palka.

7. Juru masak bertugas mengolah bahan makanan untuk konsumsi semua awak kapal, pada saat operasi penangkapan juru masak ini beralih tugas menjadi pembantu juru umpan.

Tugas masing-masing anak buah kapal selengkap dapat dilihat pada Tabel 2. 
Tabel 2. Tugas masing-masing anak buah kapal nelayan funai (kapal contoh 1) di Kwandang

\begin{tabular}{|c|c|c|c|c|}
\hline No. & $\begin{array}{l}\text { Jabatan anak } \\
\text { buah kapal }\end{array}$ & $\begin{array}{l}\text { Sebelum dan atau setelah } \\
\text { operasi penangkapan }\end{array}$ & $\begin{array}{c}\begin{array}{c}\text { Pada saat operasi } \\
\text { penangkapan ikan } \\
\text { umpan }\end{array} \\
\end{array}$ & $\begin{array}{c}\text { Pada saat operasi } \\
\text { penangkapan ikan } \\
\text { target }\end{array}$ \\
\hline 1. & Nakhoda & $\begin{array}{l}\text { Mencari gerombolan ikan dan } \\
\text { menentukan fishing ground }\end{array}$ & Mengendalikan kemudi & Sebagai juru umpan \\
\hline 2. & Juru mudi & Mengendalikan kemudi & Mengoperasikan seine net & $\begin{array}{l}\text { Mengendalikan } \\
\text { kemudi }\end{array}$ \\
\hline 3. & Pemancing & $\begin{array}{l}\text { Menyiapkan alat operasi } \\
\text { penangkapan }\end{array}$ & Mengoperasikan seine net & $\begin{array}{l}\text { Memancing ikan } \\
\text { target }\end{array}$ \\
\hline 4. & Juru umpan & Sebagai nakhoda & Mengoperasikan seine net & Pelempar umpan \\
\hline 5. & $\begin{array}{l}\text { Pembantu juru } \\
\text { umpan }\end{array}$ & Sebagai juru masak & Mengoperasikan seine net & $\begin{array}{l}\text { Memindahkan } \\
\text { umpan dari palka ke } \\
\text { bak umpan }\end{array}$ \\
\hline 6. & Juru ikan & $\begin{array}{l}\text { Menangani ikan hasil } \\
\text { tangkapan proses penataan, } \\
\text { pembekuan ikan di palka }\end{array}$ & Mengoperasikan seine net & $\begin{array}{l}\text { Memancing ikan } \\
\text { target }\end{array}$ \\
\hline 7. & Juru masak & $\begin{array}{l}\text { Membantu menyiapkan alat } \\
\text { operasional penangkapan }\end{array}$ & Mengoperasikan seine net & $\begin{array}{l}\text { Sebagai pembantu } \\
\text { juru umpan }\end{array}$ \\
\hline
\end{tabular}

\section{a. Alat Tangkap dan Cara Pengoperasian}

Pada Gambar 1 dapat dilihat bahwa alat tangkap funai terdiri atas joran, tali nylon, dan mata pancing. Joran terbuat dari bahan bambu kuning dengan diameter pada bagian pangkal 4 sampai dengan 5 $\mathrm{cm}$ dan meruncing sampai dengan ke bagian ujung. Ukuran panjang joran sekitar $6 \mathrm{~m}$. Tali utama funai terbuat dari nylon No.1.500 dan panjang $5,5 \mathrm{~m}$ sedangkan tali cabang terbuat dari nylon No.800 dan panjang $30 \mathrm{~cm}$. Mata pancing digunakan 2 jenis yaitu jenis mata pancing tanpa kait balik (nama lokal: pancing lawuh) dan pancing berkait (nama lokal: pancing duren). Ukuran mata pancing tanpa kait balik panjang $4 \mathrm{~cm}$ dan lebar $2 \mathrm{~cm}$ buatan nelayan sendiri. Ukuran mata pancing berkait panjang $4 \mathrm{~cm}$ dan lebar $1,5 \mathrm{~cm}$ (pancing No.8). Untuk menarik perhatian ikan, jenis mata pancing tanpa kait sebagian mata pancing dibungkus dengan kain tiras (semacam kain puring) dengan warna disesuaikan dengan warna ikan umpan yang akan digunakan, ada beberapa warna kain tiras seperti warna putih, merah, kuning, abu-abu, biru, hitam, dan lain-lain.

Seperti hal alat tangkap huhate, dalam pengoperasian alat tangkap funai sangat tergantung pada ketersediaan umpan hidup. Umpan hidup diperoleh dengan cara melakukan penangkapan memakai alat tangkap jaring (seine net) (Gambar 2) yang dioperasikan di perairan pantai yang ditarik oleh perahu katinting dengan menggunakan mesin Yamaha 8 PK. Daerah penangkapan ikan umpan adalah di sekitar perairan P. Raja, P. Papaya dan P. Dionumo dengan waktu tempuh sekitar 1 jam dari PPI Kwandang. Jenis-jenis ikan umpan hidup yang tertangkap di perairan tersebut adalah ikan sardin atau gisau (Sardinella sp.), dan ikan teri atau puri (Stolephorus sp.). Setelah tersedia ikan umpan, perjalanan dilanjutkan untuk menuju daerah penangkapan ikan tuna, cakalang, dan tongkol. 

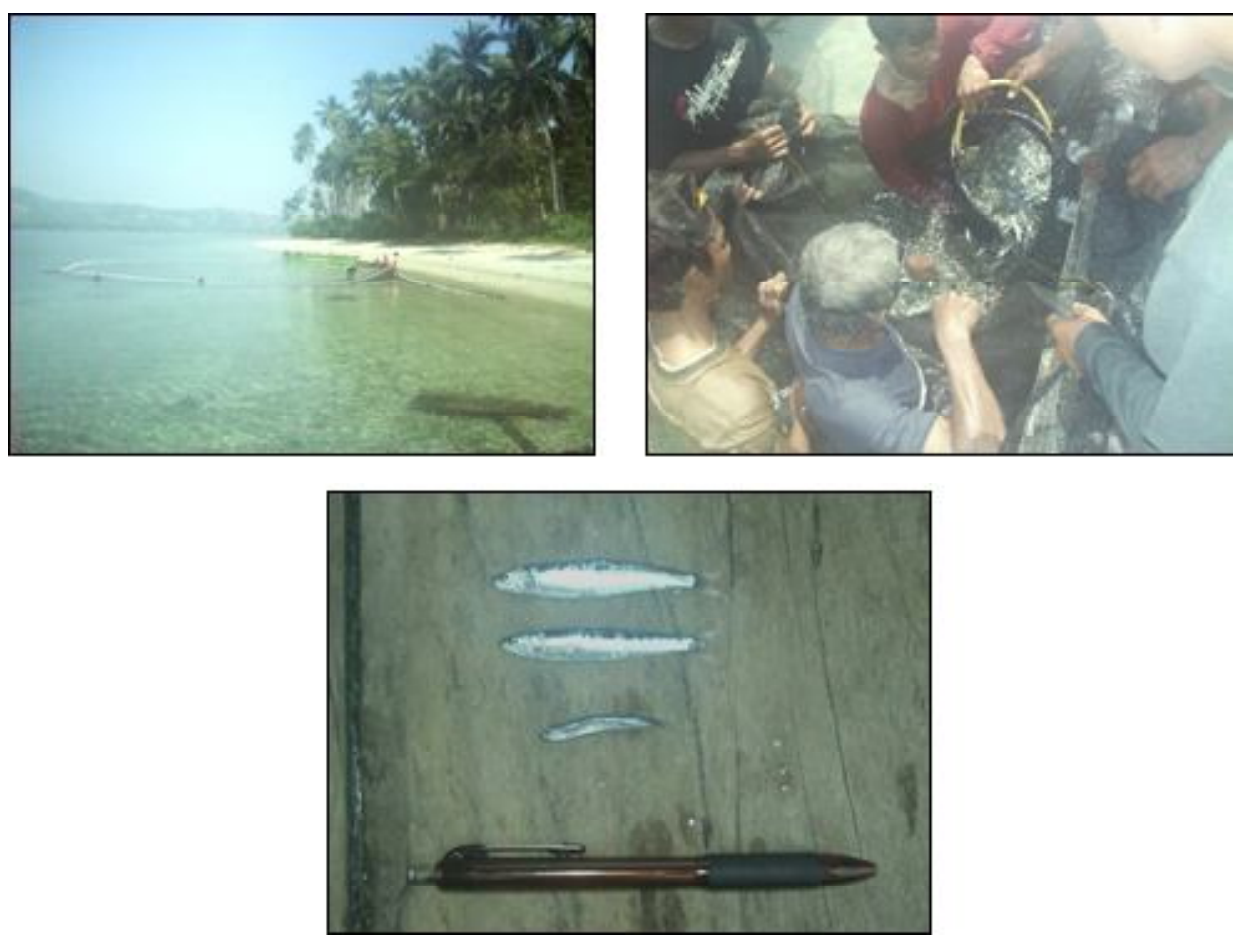

Gambar 2. Proses penangkapan ikan umpan hidup menggunakan alat tangkap seine net dan jenis ikan umpan hidup yang tertangkap.

Waktu operasi penangkapan funai dimulai pagi sampai dengan sore hari (pukul 06.00 sampai dengan 19.00). Pengoperasian dilakukan pada gerombolan ikan tuna, cakalang, atau tongkol. Gerombolan ikan tersebut kemudian dirangsang dengan lemparan umpan hidup dan semprotan air supaya mendekati kapal. Setelah ikan-ikan berada pada Iahan penangkapan kemudian dilakukan penangkapan atau

pemancingan dengan menggunakan joran, tali, dan mata pancing (Gambar 3). Pancing yang digunakan jenis pancing tanpa kait balik sehingga ikan yang tertangkap akan mudah dilepaskan. Sedangkan jenis pancing berkait digunakan apabila ikan target tidak dapat dipancing dengan menggunakan jenis pancing tanpa kait balik.

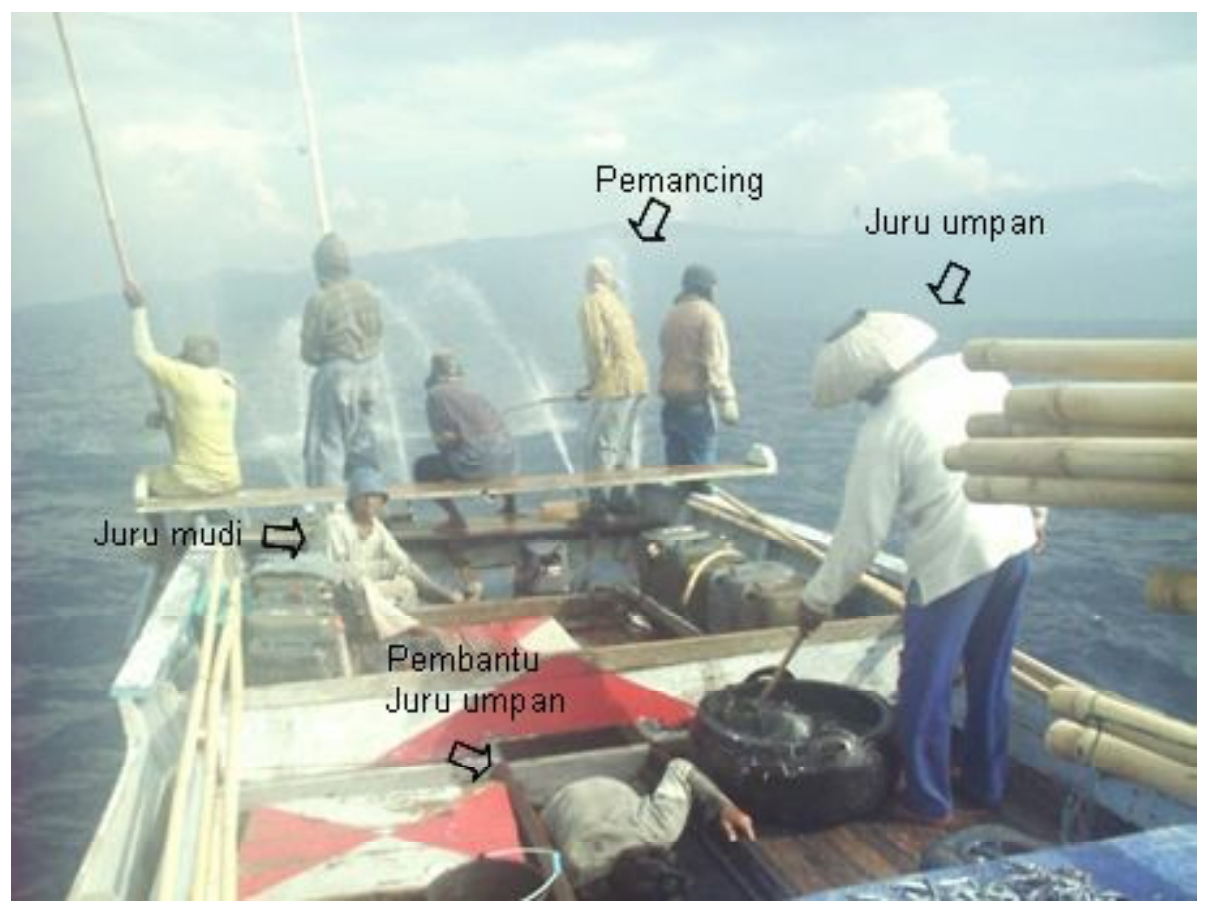

Gambar 3. Awak kapal sedang mengoperasikan alat tangkap funai. 


\section{a. Komposisi Hasil Tangkapan}

Jenis ikan pelagis besar yang merupakan target penangkapan dari alat tangkap funai nelayan Kwandang adalah jenis cakalang (Katsuwonus pelamis), tuna madidihang (Thunnus albacares), dan ikan tongkol pipih (Euthynus affinis), dan tongkol bulat (Auxis thazard), hal ini sama dengan jenis ikan yang merupakan target penangkapan huhate (Balai Riset Perikanan Laut, 2005).

Total hasil tangkapan yang diperoleh alat tangkap funai pada trip ini $44,8 \mathrm{~kg}, 97 \%$ dan tongkol bulat $3 \%$.
Dari hasil pengambilan contoh yang terdiri atas jenis ikan tongkol yaitu ikan tongkol pipih sebesar dilakukan di atas kapal diperoleh kisaran panjang cagak (FL) tongkol pipih antara 24,6 sampai dengan $37,0 \mathrm{~cm}$ dengan ukuran yang banyak tertangkap pada ukuran $32 \mathrm{~cm} \mathrm{24 \%} \mathrm{(Gambar} \mathrm{4).} \mathrm{Pada} \mathrm{trip} \mathrm{ini} \mathrm{jenis} \mathrm{ikan}$ cakalang tidak tertangkap. Menurut nelayan pada saat penelitian ini berlangsung belum terjadi musim ikan cakalang. Seperti diketahui puncak musim penangkapan ikan cakalang untuk daerah di kawasan timur Indonesia adalah sekitar musim peralihan I (bulan April, Mei, dan Juni) sampai dengan awal musim timur (Balai Riset Perikanan Laut, 2004).

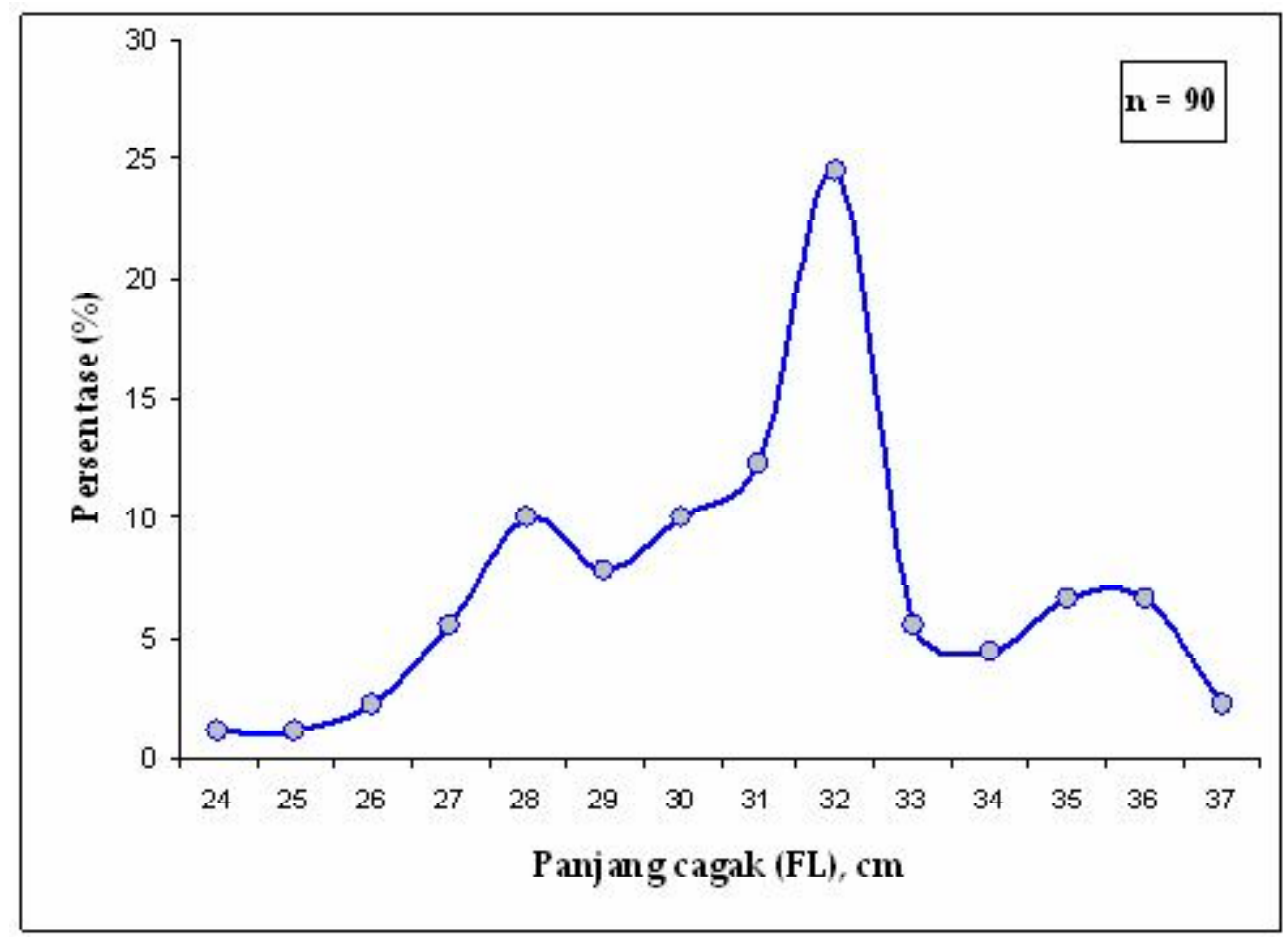

Gambar 4. Frekuensi panjang ikan tongkol hasil tangkapan kapal Funai, bulan September 2005.

\section{Daerah Penangkapan}

Nelayan funai melakukan operasi penangkapan di sekitar rumpon atau ponton yang telah dipasang di perairan Laut Sulawesi. Ketika itu sebagian besar rumpon dan ponton tersebut telah putus dan hanyut terbawa arus. Dengan tidak ada rumpon-rumpon atau ponton-ponton tersebut, penangkapan ikan tuna, cakalang dan tongkol yang merupakan sasaran utama dari alat tangkap funai dilakukan pada gerombolan ikan tersebut yang ditandai dengan ada gerombolan ikan lumba-lumba atau ada kawanan burung laut yang terbang mendekati permukaan laut. Selama trip, operasi penangkapan dilakukan di sekitar perairan Sumalata (sebelah barat Laut Kwandang) yang banyak terdapat gerombolan ikan lumba-lumba dan kawanan burung laut. Pengaruh rumpon atau ponton pada operasi penangkapan funai sangat besar, ini terbukti pada saat mencari fishing ground sangat susah apabila tidak ada rumpon atau ponton. Gerombolan ikan di luar rumpon lebih cepat berpindah (berenang) ke tempat lain, dibandingkan gerombolan ikan yang terdapat di rumpon. 


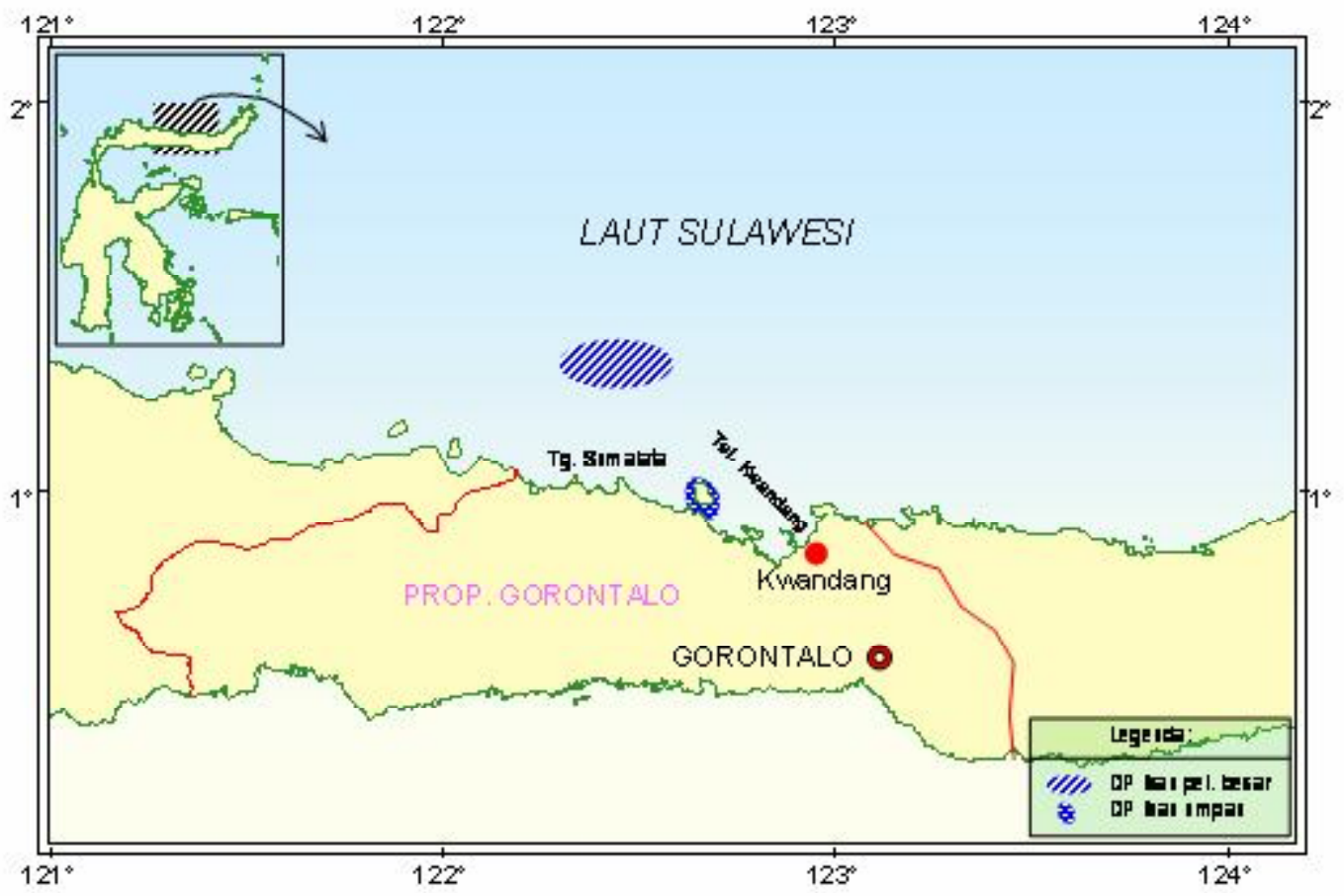

Gambar 5. Daerah penangkapan kapal funai, bulan September 2005.

\section{KESIMPULAN}

1. Alat tangkap funai mirip dengan huhate mini (mini pole and line).

2. Alat tangkap funai dioperasikan di bagian buritan kapal.

3. Usaha penangkapan funai tergantung pada tersedia umpan hidup.

4. Daerah penangkapan funai lebih mudah dilakukan di sekitar rumpon.

5. Jenis ikan yang menjadi sasaran penangkapan alat tangkap funai adalah jenis ikan tuna, cakalang, dan tongkol.

\section{DAFTAR PUSTAKA}

Balai Riset Perikanan Laut. 2004. Musim penangkapan ikan di Indonesia. Balai Riset Perikanan Laut. Pusat Riset Perikanan Tangkap. Badan Riset Kelautan dan Perikanan. Departemen Kelautan dan Perikanan. Jakarta 2004. 116 hal.

Balai Riset Perikanan Laut. 2005. Teluk Tomini: Ekologi, potensi sumber daya, profil perikanan, dan biologi beberapa jenis ikan ekonomis penting. Balai Riset Perikanan Laut. Pusat Riset Perikanan Tangkap. Badan Riset Kelautan dan Perikanan. 2005. 114 hal.

Subani, W. \& H. R. Barus. 1989. Alat penangkapan ikan dan udang laut di Indonesia (fishing gears for marine fish and shrimp in Indonesia). Jurnal Penelitian Perikanan Laut (Edisi Khusus). No.50 tahun 1988/1989. 248 hal. 